Електронне наукове фахове видання "Ефективна економіка" включено до переліку наукових фахових видань України з питань економіки

(Наказ Міністерства освіти і науки України від 11.07.2019 № 975) www. economy.nayka.com. ua | № 11, 2019 | 28.11.2019 p.

DOI: $10.32702 / 2307-2105-2019.11 .67$

УДК 338:658:115

Iryna V. Farynovych

PhD in Economics, Senior Lecturer of the Finance, Account and Analysis Department «Lviv Polytechnic» National University, Lviv, Ukraine

ORCID: 0000-0002-0467-8578

Khrystyna P. Danylkiv

PhD in Economics, Senior Lecturer of the Finance, Account and Analysis Department «Lviv Polytechnic» National University, Lviv, Ukraine

ORCID: 0000-0003-1283-6844

Nataliia Y. Hembarska

PhD in Economics, Senior Lecturer of the Finance, Account and Analysis Department «Lviv Polytechnic» National University, Lviv, Ukraine

ORCID: 0000-0002-7839-4260

\title{
FACTORS INFLUENCE ON THE EFFICIENCY OF MANAGEMENT OF THE MUNICIPAL ENTERPRISES
}

\section{I. В. Фаринович,}

к. е. н., старший викладач кафедри фінансів, обліку і аналізу

Національного університету «Львівська політехніка», м. Львів

Х. П. Данилків,

к. е. н., старший викладач кафедри фінансів, обліку і аналізу

Національного університету «Львівська політехніка», м. Львів

Н. Є Гембарська,

к. е. н., старший викладач кафедри фінансів, обліку і аналізу

Національного університету «Львівська політехніка», м. Львів

\section{ФАКТОРИ ВПЛИВУ НА ЕФЕКТИВНІСТЬ УПРАВЛІННЯ КОМУНАЛЬНИХ ПШДПРИЕМСТВ}

The quality of housing and communal services depends on the high standard of living of the society. Therefore, a significant branch of the national economy of the country is the utility industry. However, the poor technical condition of the industry leads to a decrease in the quality of services provided and has a negative impact on the environment. Effective management of a utility company is possible through rapid response to changes in the external and internal environment. Therefore, the study of internal and external factors influencing the efficiency of the management of utility companies is relevant and of particular importance. The article analyzes the views of domestic scientists on the essence of the concept of "utility company". The list of factors that, in certain circumstances, may affect the development of public utilities is summarized. The internal factors influencing the efficiency of management of communal enterprises are characterized. The influence of external factors on the management activity of enterprises, in particular, enterprises of the communal sector is considered. Groups of factors that stimulate the development of enterprises have been identified and investigated. It is revealed that the main groups of factors that absorb the development of public utilities are: political, legal, organizational, economic, social, scientific, technological, environmental and climate. The factors of direct and indirect impact on the external 
and internal environment of enterprises are characterized. It is found that environmental factors affect the economic security of the enterprise, and internal - are considered as derived from them. In the course of the research the interdependence of internal and external factors of influence on the activity of public utilities was revealed. It should be noted that changes in external factors affect changes in the internal environment of utility companies. The results of the study are summarized.

Від якості житлово-комунальних послуг залежить високий рівень життя суспільства. Тому вагомою галуззю народного господарства краӥни є комунальна галузь. Однак, незадовільний технічний стан иієї галузі призводить до зниження якості наданих послуг та чинить негативний вплив на навколишне середовище. Ефективне управління підприємством комунального господарства можливе шляхом швидкого реагування на зміни зовнішнього та внутрішнього середовище. Тому, дослідження внутрішніх та зовнішніх факторів впливу на ефективність управління діяльністю комунальних підприємств є актуальним та набуває особливого значення. У статті проаналізовано бачення вітчизняних науковців щуодо сутності поняття «комунальне підприємство». Узагальнено перелік факторів, що, за певних обставин, можуть вплинути на розвиток підприємств комунального господарства. Охарактеризовано внутрішні фактори, що впливають на ефективність управління комунальними підприємствами. Розглянуто вплив зовнішніх факторів на управлінську діяльність підприємств, зокрема, підприємств комунальної галузі. Виокремлено та досліджено групи факторів, які є дестимуляторами розвитку підприємств. Виявлено, щчо основними групами факторів, які впивають на розвиток комунальних підприємств є: політично-правові, організаційно-економічні, соціальні, науково-технологічні, екологічні та кліматичні. Охарактеризовано фактори прямої та непрямої дї на зовнішне та внутрішне середовище підприємств. Виявлено, що фактори зовнішнього середовища впливають на економічну безпеку підприємства, а внутрішні - розглядаються як похідні від них. В прочесі дослідження виявлено взаємозалежність внутрішніх та зовнішніх факторів впливу на діяльність підприємств комунального господарства. Зазначимо, щзо зміна зовнішніх факторів впливає на зміни у внутрішньому середовищі діяльності комунальних підприємств. Узагальнено результати дослідження.

Keywords: external factors; internal factors; efficiency; management; utility.

Ключові слова: зовнішні фактори; внутрішні фактори; ефективність; управління; комунальне підприємство.

Formulation of the problem. A prerequisite for the development of any business entity is the achievement of its effectiveness, which is defined as the ability of the enterprise to receive additional financial resources from the invested capital, that is, to achieve the set goals. However, in conditions of economic instability, the level of enterprise development is influenced by factors of the external and internal environment. Therefore, research into the factors influencing the activity of enterprises is a particularly pressing issue today.

Analysis of recent research and publications. Investigation of factors of influence on the efficiency of enterprise management is considered in the writings of the following scientists: A. M. Sukhorukova, N. N. Pashkang, L. I. Fedulova, M. V. Kovbatiuk, N. G. Benik and others. Some aspects of the functioning of public utilities and determining the impact of factors on their development were studied by the following scientists: I. P. Pikhtar, V. Y. Svitlychnaya, V. G. Podlesna, O. M. Lukyanchuk, T. I. Skibina. However, it is necessary to determine the interdependence of the factors of internal and external influence on the management of utility companies.

Formulating the goals of the article. The main purpose of the article is to investigate the factors of external and internal influence on the development and efficiency of management of utilities.

Outline of the main research material. A utility company is a complex system of an economic complex of a country, the level of development of which is influenced by many factors of internal and external environment. Factors affecting housing and communal services can be objective and subjective.

Many scientists believe that environmental factors have a greater impact on the development of an enterprise than environmental factors.

Thus, Sukhorukova A. M. and Pashkang N. N. it is also believed that the influence of external factors takes precedence over internal [10].

However, in our opinion, the factors of both the external and internal environment are closely influenced by the close interaction. 
Fedulova L. I. cites the following factors of influence of the internal environment: finance, technology, personnel policy and organization and management [13].

According to Podlesnoy V. G. [7] it is possible to distinguish the following groups of factors, which are the stimulators of enterprise development, including the enterprises of housing and communal services:

- financial (since housing and communal services require renovation and reconstruction of fixed assets, therefore there is an additional need for financing);

- Transformational (since there is a need to create an effective mechanism for controlling the volume and quality of services provided and their compliance with the price);

- information (low awareness of the population on the formation of tariffs for utilities);

- outlook (lack of awareness of the management staff of housing and communal services and local selfgovernment bodies of the need to adhere to the principles of sustainable development; indifferent attitude of household consumers to the account of used resources and resource saving; household budgets [7, pp. 132-133].

On internal factors Kniaz O. V. attributes the organizational structure of management, activities, technologies, resources, social and psychological climate in the enterprise [2].

According to Brovkina Yu. O. environmental factors affect the economic security of an enterprise, while internal factors are regarded as derived from it, since the resources of the enterprise are obtained from the external environment [1].

Investigating the influence of factors on the development of utility companies Svitlichna V. Yu. proposes to distinguish three levels of environment, namely: external, direct and internal.

The author attributes to environmental factors [8]:

- political;

- economic;

- social;

- environmental;

- technological;

- the international environment.

Factors of direct (direct) influence, according to the author [8], are:

- labor market,

- suppliers,

- competitors,

- intermediaries,

- consumers,

- contact audiences.

Internal factors influencing the development of the activity of enterprises of the communal sector Svitlichna V. Yu. considers [8]:

- experience of functioning of enterprises in the market,

- marketing,

- innovative,

- financial and energy saving policy of enterprises,

- the quality of their assets,

- level of remuneration,

- state of the production base,

- qualification level of personnel, etc.

Thus, Kovbatiuk M. V. and Benik N. G. distinguish external factors of direct and indirect action. Such factors affect both the external and internal environment of the enterprise.

The external factors of indirect action according to the authors [3] include:

- organizational and managerial;

- socio-economic;

- political;

- environmental;

- natural and climatic;

- production and technological;

- scientific and technical;

- foreign economic.

External factors of direct effect on the external and internal environment of enterprises include [3]: suppliers of resources; banks and credit institutions; consumers; competitors; intermediaries; transport connection; information and more.

Kovbatiuk M. V. and Benik N. G. believe that external factors affect the functioning of the enterprise and disrupt its financial condition, so business entities need to perform a comprehensive diagnosis of the internal environment (using retrospective, operational and prospective analysis) in order to identify the level of adaptability of the enterprise to external [3].

Tulenkov N. identifies the following factors that affect the effectiveness of management [12]:

- favorable external environment;

- a properly formed strategy;

- the quality of human and especially management resources. 
Maksimtsov M. M., Ignatieva A. V. believes that the main factors influencing the activity of the company are

- potential of the labor collective;

- means of production;

- social aspects of the enterprise;

- the culture of the organization.

Pyhtar I. P. provides a generalized classification of factors, dividing them by [6]:

1. Endogenous (direct), which is attributed to technical, technological and institutional factors.

2. Exogenous (indirect), including economic, social and climatic factors [6].

According to R. Kaplan and D. Norton, the factors that influence the development of an entity include:

- factors of financial activity;

- relations with consumers;

- factors of internal business processes;

- training and development of employees.

Factors influencing the efficiency of the enterprise, according to Zhuravleva, P. V., Sedegova R. S. and Yanchevsky V. G. are [11]:

- managerial work;

- economy of the management system;

- production functioning.

In his work, Lukyanchuk O. M. proposes the following groups of factors that have a certain impact on the efficiency of enterprise development, adapted to the utility enterprise [4]:

1) political and legal factors:

- legal regulation (existence of legislative norms and standards, introduction of world ISO standards, perfection and humanity of adopted legal documents, absence of contradictions, etc.);

- corruption and bureaucracy (absence of the phenomenon of money laundering, openness of tariff formation, free access to information, etc.).

2) organizational and economic factors:

- level of investment attractiveness (formation of conditions for attractiveness of the industry for investors);

- financial, investment and economic sustainability of enterprises (availability of equity capital, positive financial performance indicators);

- the presence of a competitive environment and the market of housing and communal services as a whole (the ability of consumers to choose the entities providing services);

- level of qualification of employees, their number and experience (availability of necessary skills and skills to increase productivity);

- efficiency of management and organizational activity (perfect system of influences on the wards, cooperation with state authorities and consumers, control over work, etc.).

3) social factors:

- demographic structure of the population (gender, age structure, ratio of population groups by level of education, culture, income, etc.);

- activity of the population (initiative, desire to participate in the processes of improvement, home improvement, etc.);

- settlement system (there are significant differences in rural and urban development).

4) scientific and technological factors:

- state of communal infrastructure (presence of dilapidated and emergency systems, their level of wear, age, number of losses, etc.);

- complexity of work (the amount of time spent on performing a unit of production); resources);

- availability of production facilities (for operation of all possible capacities, maximum use of available

- the level of implementation of research and development (attracting new inventions in production);

- introduction of new technologies, etc.

5) environmental factors:

- chemical composition of water, soils;

- area and density of green space;

- volumes of harmful emissions into water, atmosphere, soils, etc .;

- solid waste volumes, their removal and disposal;

6) climatic factors:

- average air temperature by seasons;

- humidity level;

- rainfall;

- wind speed, etc.

Skibina T.I. proposes to divide factors into two groups [9]:

- external macro level;

- external micro level.

External macro level factors the author proposes to determine by the method of T.E.M.P.L.E.S. (Technology, Economics, Market, Politics, Laws, Ecology, Society), and special attention should be paid to the relationship with 
consumers and suppliers, regarding the influence of microlevel environmental factors. However, the author [9] considers it necessary to investigate the influence of internal factors on the economic environment.

The interdependence of internal and external factors influencing the development of public utilities is shown in

Fig. 1.

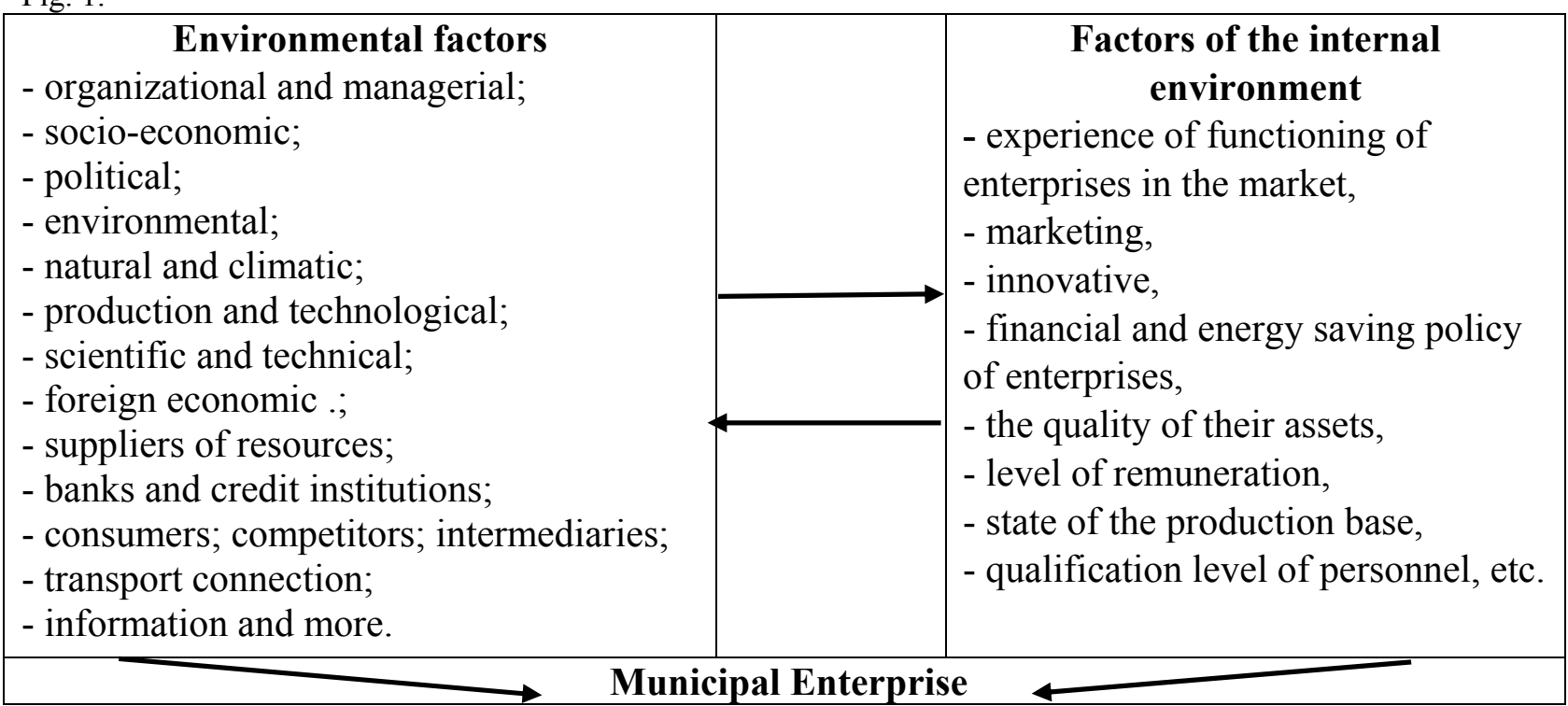

Fig. 1. Interdependence of internal and external factors influencing the development of utility companies Source: generated by the authors on the basis of [3; 8; 9]

Conclusions from this study. Summarizing the above, it can be argued that the factors that have an impact on the efficiency of managing utilities are interrelated and interacting. In order to increase the efficiency of management of utilities, it is necessary to take into account the results of the influence of an individual factor, as well as to take into account the fact that, together, the above factors create a system of influence on the effectiveness of management. It should be noted that changes in external factors affect changes in the internal environment of utility companies.

\section{References.}

1. Brovkina, Yu.O. (2015), "Factors of the internal environment and their impact on the economic security of baking enterprises", Visnyk Skhidnoievropejs'koho universytetu ekonomiky i menedzhmentu, vol. 1(18), pp. 93-99.

2. Kniaz, O.V. (2006), "Analysis and evaluation of factors that influence the level of innovative development of enterprises", Ekonomika promyslovosti, vol. 3, pp. 128-135.

3. Kovbatiuk, M.V. and Benyk, N.H. (2016), "Influence of factors of external and internal environment on the process of functioning and adaptation of enterprises", Vodnyj transport, vol. 2(25), pp. 101-108.

4. Lukyanchuk, O.M. (2013), "Influence of factors of external and internal environment on the process of functioning and adaptation of enterprises", Heohrafiia ta turyzm, vol. 26, pp. 207-214.

5. Maximsov, M.M. Ignatiev, A.V. and Komarov, M.A., (1999), Menedzhment [Management], Banky y byrzhy, YuNYTY, Moscow, Russia.

6. Pikhtar, I.P. (2013), "Ensuring sustainable development of the housing and communal complex of the region: territorial and sectoral aspects”, Ph.D. Thesis, Economy, Cherkasy State Technological University, Cherkasy, Ukraine.

7. Podlesna, V.G. (2008), "Problems of housing and communal services reform", Mekhanizm rehuliuvannia ekonomiky, vol. 3, T.2, pp. 132-136.

8. Svitlichna, V. Yu. (2004), "Economic strategy of housing and communal services development: formation, specificity, prospects”, Kommunal'noe khoziajstvo horodov: naukovo-tekhnycheskyj sbornyk, Seryia: Ekonomycheskye nauky, vol. 59, pp. 78-85.

9. Skibina, T.I. (2017), "Evaluation of the efficiency of enterprise management in the provision of public utilities", Abstract of Ph.D. dissertation, Economy, Kherson, Ukraine.

10. Sukhorukova, A.M. and Pashkang N.N. (2000), "The result of the transformation of the food industry management system in the region", Pyschevaia promyshlenost', no. 9, pp. 15-19.

11. Zhuravleva, P.V. Sedegova, R. S. and Yanchevsky, V. G. (2002), Teoryia systemnoho menedzhmenta [Theory of systems management], Exam, Moscow, Russia.

12. Tulenkov, N. (1997), "Social Management Efficiency”, Staff, vol. 2, pp. 3-7.

13. Fedulova, L.I. (2003), Menedzhment orhanizatsij [Management of Organizations], Lybid, Kyiv, Ukraine.

\section{Список використаних джерел.}

14. Бровкіна Ю.О. Фактори внутрішнього середовища та їхній вплив на економічну безпеку хлібопекарських підприємств // Вісник Східноєвропейського університету економіки і менеджменту. - Випуск 1 (18). - 2015. - c. 93-99 
15. Князь О.В. Аналіз та оцінювання факторів, які впливають на рівень інноваційного розвитку підприємств / О.В. Князь // Економіка промисловості. - 2006. - №3. - с. 128-135

16. Ковбатюк М.В. Вплив факторів зовнішнього i внутрішнього середовища на процес функціонування та адаптації підприємств / М.В. Ковбатюк, Н.Г. Беник // [Електронний ресурс]. - Режим доступу: irbis-nbuv.gov.ua/cgi-bin/irbis_nbuv/cgiirbis_64.exe

17. Лук'янчук О.М. Фактори розвитку та ефективної діяльності житлово-комунального господарства / О.М. Лук'янчук // Географія та туризм. - с. 207-214 - [Електронний ресурс]. - Режим доступу: irbisnbuv.gov.ua/cgi-bin/irbis_nbuv/cgiirbis

18. Менеджмент: учебник для вузов / М.М. Максимцов, А.В. Игнатьева, М.А. Комаров и др.; под. ред. М.М. Максимцова, А.В. Игнатьевой. - М.: Банки и биржи, ЮНИТИ, 1999. - 343 с.

19. Піхтар I. П. Забезпечення сталого розвитку житлово-комунального комплексу регіону: територіально-галузевий аспект [Текст] : автореф. дис. ... канд. екон. наук : 08.00.05 / Піхтар Ілона Павлівна ; Черкас. держ. технол. ун-т. - Черкаси, 2013. - 20 с.

20. Подлєсна В. Г. Проблеми реформування житлово-комунального господарства / В. Г. Подлєсна // Механізм регулювання економіки. - 2008. - № 3. - Т. 2. - С. 132-136.

21. Світлична В. Ю. Економічна стратегія розвитку житлово-комунального господарства: формування, специфіка, перспективи / В. Ю. Світлична // Коммунальное хозяйство городов : науковотехнический сборник. - К. : Техника, 2004. - Вип.59. - С. 78-85. - (Серия : Економические науки).

22. Скібіна T.I. Оцінювання ефективності управління підприємствами із надання комплексу комунальних послуг [текст] : дис. к.-та екон. наук : 08.00.04 / Скібіна Тетяна Ігорівна, Херсон. - 2017. - с. 225

23. Сухорукова А.М. Результат трасформации системы управления пищевой промышленностью региона / А.М. Сухорукова, Н.Н. Пашканг // Пищевая промышленость. - 2000. - №9. - с. 15-19

24. Теория системного менеджмента: учебник. / под общ. ред. П.В. Журавлева, Р. С. Седегова, В. Г. Янчевского. - М.: Издательство «Экзамен», 2002. - 516 с.

25. Туленков Н. Социальная эффективность управления / Н. Туленков // Персонал. - 1997. - № 2. - С.

26. Федулова Л.І. Менеджмент організацій: Підручник. / Л.І. Федулова - К.: Либідь, 2003. - 448 с.

Стаття надійшла до редакиіï 11.11.2019 p. 